\title{
DEVELOPING CONTINUOUS-CASTING-PROCESS CONTROL BASED ON ADVANCED MATHEMATICAL MODELLING
}

\author{
UPORABA NAPREDNEGA MATEMATIČNEGA MODELIRANJA ZA \\ RAZVOJ KONTROLE POSTOPKA KONTINUIRNEGA ULIVANJA
}

\author{
Jan Falkus, Katarzyna Miłkowska-Piszczek \\ Faculty of Metals Engineering and Industrial Computer Science, AGH University of Science and Technology, Al. Mickiewicza 30, 30-059 \\ Kraków, Poland \\ jfalkus@agh.edu.pl
}

Prejem rokopisa - received: 2014-08-03; sprejem za objavo - accepted for publication: 2014-12-16

The method of continuous casting of steel - due to its ability to maximize the yield of liquid steel, along with substantially reducing the energy consumption of the production process - has become the fundamental method for obtaining steel semi-products. Nowadays, over $90 \%$ of the global steel is cast with the continuous method. In recent years the ability to numerically model metallurgical processes - including the continuous process of steel casting - has been very important for creating new technologies, along with modifying those that already exist. The mathematical modelling of solidification processes with numerical methods allowed a full comprehensive reconstruction of the complex physical and chemical nature of the solidification processes. However, having to formulate a numerical model of the continuous-casting process is an extremely complex task because the requirements stipulate that a correct set of material parameters, along with the process data, have to be implemented. As regards the formulation of a mathematical model of the steel continuous-casting process, a comprehensive description of the heat transfer during the continuous casting is an important item. The complexity of this issue requires that conscious simplifications are made when formulating mathematical models for the calculation of the cast-strand solidification process. The number and type of the simplifications - which are necessary in this case - are the keys to the correctness of the results obtained, and they also influence the scope and accuracy when it comes to verifying the model. It is crucial to define the problem on the basis of the finite-element theory, and the elimination of numerical errors is obviously a necessary condition to ensure the correctness of the analysis performed. This paper contains a description of a number of solutions that are based on the finite-element method (FEM) for the models using the Euler, Lagrange and MiLE meshes. All the model concepts are illustrated with the examples of the calculations that were completed using the actual industrial data, along with the properties of the materials as determined by laboratory tests. The pivot of the considerations conducted is related to the verification of the correctness of the calculations, together with the sensitivity analysis of individual model types. The conclusions present an assessment of the progress of the current numerical models of the continuous-casting process, along with the directions for their further development.

Keywords: continuous casting, mathematical modelling, solidification, process control

Metoda kontinuirnega ulivanja jekla je postala osnovna metoda za pridobivanje jeklenih polproizvodov zaradi možnosti maksimalnega izkoristka staljenega jekla ter zmanjšanja porabe energije za proizvodni proces. Danes je okrog $90 \%$ svetovne proizvodnje jekla ulitega $z$ metodo kontinuirnega ulivanja. V preteklih letih je bila možnost modeliranja postopka ulivanja jekla zelo pomembna pri nastajanju novih tehnologij vključno z modificiranjem že obstoječih. Matematično modeliranje procesa strjevanja $\mathrm{z}$ numeričnimi metodami je omogočilo celovito rekonstrukcijo kompleksne fizikalne in kemijske narave procesa strjevanja. Vendar pa je postavitev numeričnega modela postopka kontinuirnega ulivanja zelo zahtevna naloga, ker zahteve določajo, da je treba uporabiti pravilne parametre materiala vključno s podatki procesa. Glede na postavitev matematičnega modela postopka kontinuirnega ulivanja je pomembna postavka celovit opis prenosa toplote med kontinuirnim ulivanjem. Kompleksnost tega vprašanja zahteva zavestne poenostavitve pri postavitvi matematičnih modelov za izračun procesa strjevanja žile. Śtevilo in vrsta poenostavitve, ki so v tem primeru nujne, sta ključ za pravilnost dobljenih rezultatov, vplivajo pa tudi na obseg in natančnost, ko pride do preverjanja modela. Ključnega pomena je definiranje problema, ki temelji na teoriji metode končnih elementov, odprava numeričnih napak pa je očitno potrebni pogoj za zagotovitev pravilnosti izvršenih analiz. Članek vsebuje opis številnih rešitev, ki temeljijo na metodi končnih elementov (FEM), za modele, ki uporabljajo Euler-jevo, Lagrange-jevo in MiLE-mrežo. Prikazani so vsi koncepti modelov z izračuni, ki so bili dopolnjeni z uporabo pravih industrijskih podatkov, skupaj z lastnostmi materialov, kot je bilo določeno v laboratorijskih preizkusih. Težišče izvršenih obravnav je povezano s preverjanjem pravilnosti izračunov, skupaj z občutljivo analizo posameznih vrst modelov. V sklepih je predstavljena ocena glede napredovanja sedanjih numeričnih modelov postopka kontinuirnega ulivanja vključno z napotki za njihov nadaljnji razvoj.

Ključne besede: kontinuirno ulivanje, matematično modeliranje, strjevanje, kontrola procesa

\section{INTRODUCTION}

The history of the development of the steel continuous-casting process is an interesting example of the implementation of an idea that was well ahead of its time. After H. Bessemer had applied for the first patent in 1846, 34 years had to pass before the inventor made his first trials of steel casting at the semi-technical scale. ${ }^{1}$
The reasons why the idea of the metal continuous-casting process was so inspiring for many metallurgical engineers are well known. The implementation of this process to steel casting significantly shortened the process line, definitely reducing both the process and the investment costs. The other indisputable reason for the advantage of steel continuous casting over ingot casting is the yield. Thanks to a yield increase of over $10 \%$, it 
became possible to increase the steelworks output without increasing the steelmaking furnace capacity.

The reasons why the implementation of the steel continuous-casting process for the production took so long are as well understood as the reasons for its implementation. From the outset, the mechanical characteristics of a strand cast have been the main difficulty, as a strand is prone to cracking, especially at the initial formation stage; in an extreme case it may even break out. A small shell thickness of a strand leaving the mould is of key importance. This problem is exceptionally serious as regards steel and it arises from a relatively low value of the heat-conductivity coefficient of steel as compared to the other metals. For most non-ferrous metals, the liquid core of a strand cast continuously is much shorter and the solidification process ends right under the mould. For steel, the length of the liquid core most often ranges from a few metres to something between ten and twenty. This fact brings about the necessity of using advanced techniques of the process control and ensuring stable process conditions.

Note that despite the indisputable successes, the current development of the steel continuous-casting process cannot be considered finished. The problems related to the strand breakout or the occurrence of various defects of cast strands are still valid. The financial means earmarked for scientific research related to the continuous casting of steel indirectly prove that the problems still exist. An example of a research area that constitutes a huge challenge, both in theory and in practice, is the continuous casting of peritectic steels. Engineering new steel grades also involves the need for developing their casting process from scratch. Therefore, any projects related to the improvement of the mathematical description of the steel continuous-casting process are valuable for facilitating the process control problem.

\section{STEEL CONTINUOUS-CASTING PROCESS AS AN OBJECT OF MODELLING}

The effect of a continuous-casting-machine design on the method of mathematical modelling of the steel solidification process is significant. Without the knowledge of the machine technical documentation, it is difficult to make any attempt at modelling, aiming at obtaining the results intended for use for the process control.

Despite the existing differences in the design of individual machines, one should note that it is possible to generalise the problem and form the construction of a mathematical model assuming the occurrence of two cooling zones of the strand, i.e.:

- the primary cooling zone (including the mould)

- the secondary cooling zone (including the so-called cooling chamber and the division into the cooling zones independent of the cooling chamber).
Each of the two mentioned zones is characterised by two groups of parameters - the first one may be defined as a geometrical characteristic, and the other one as a set of parameters related to the heat transfer and the properties of the steel cast. The description of the heat-transfer model for the steel continuous-casting process is a complex task as all three heat-transfer mechanisms occur - conduction, radiation and convection $^{2-4}$. The following processes impact the heat transfer in the primary zone:

- conduction and convection in the liquid-steel area,

- conduction in the solidified shell,

- heat transfer between the outer layer of the solidified shell and the mould wall surface through an air gap forming in the mould,

- heat conduction in the mould,

- heat transfer in the mould between the channel walls and the cooling water.

The main processes in the secondary cooling zone are:

- heat transfer by convection,

- heat transfer by radiation,

- heat transfer by conduction between the solidifying strand and the rolls.

Additionally, thermal effects related to the phase transitions that accompany the solidification have a significant influence on the heat-transfer model.

The heat-transfer model was used for further considerations, wherein the temperature field could be determined by solving the Fourier Equation:

$\frac{\partial\left(\rho c_{\mathrm{p}} T\right)}{\partial t}=\frac{\partial}{\partial x}\left(\lambda \frac{\partial T}{\partial x}\right)+\frac{\partial}{\partial y}\left(\lambda \frac{\partial T}{\partial y}\right)+\frac{\partial}{\partial z}\left(\lambda \frac{\partial T}{\partial z}\right)+Q$

where $\rho$ is the density, $\mathrm{kg} \mathrm{m}^{-1} ; c_{\mathrm{p}}$ is the specific heat, $\mathrm{kJ} \mathrm{kg}^{-1} \mathrm{~K}^{-1} ; \lambda$ is the thermal conductivity, $\mathrm{W} \mathrm{m} \mathrm{m}^{-1} \mathrm{~K}^{-1}$; $t$ is the time, s; $T$ is the temperature, $\mathrm{K} ; Q$ is the heatsource term, $\mathrm{W} \mathrm{m}^{-3} ; x, y, z$ are $3 \mathrm{D}$ coordinate axes. The solution of the Fourier Equation should meet those boundary conditions declared on the strand surface. In the numerical model of the steel continuous-casting process discussed, these boundary conditions may be declared in three various ways. The Equation below describes the second and third types of boundary conditions:

$$
Q=F l u x+\alpha\left(T-T_{\mathrm{a}}\right)+\sigma \varepsilon\left(T^{4}-T_{\mathrm{a}}^{4}\right)
$$

where Flux is the heat flux, $\mathrm{W} \mathrm{m}^{-2} ; \alpha$ is the heattransfer coefficient, $\mathrm{W} \mathrm{m} \mathrm{m}^{-2} \mathrm{~K}^{-1} ; T_{\mathrm{a}}$ is the ambient temperature, $\mathrm{K} ; \sigma$ is the Stefan-Bolzmann constant, $\mathrm{W} \mathrm{m}^{-2} \mathrm{~K}^{-4} ; \varepsilon$ is the emissivity. The heat flux in the model may be defined directly as the Flux value (the Neumann condition), as well as with the convection ( $\alpha$ - substitute heat-transfer coefficient) and with the radiation models ( $\varepsilon$ - emissivity).

It is a complicated task to formulate a model of the heat transfer in the mould. The main difficulty is the 
effect of an air gap formed immediately after the steel has cooled to the solidus temperature, under the liquidsteel meniscus surface. The oscillatory movement of the mould and, in addition, the strand movement in the mould with a variable casting speed, strongly influence the actual dimensions of the gap. The presence of the mould powder and gases within the gap makes this description even more problematic. The physical properties and the chemical composition of the mould powders applied significantly influence the heat-resistance value. The development of the air gap causes a very high temperature gradient between the solidifying strand shell and the mould wall. Also, the change in the air-gap dimensions during the continuous-casting process may influence the stability of the process, having an impact on the thickness of the shell leaving the mould. The dimensions of the air gap increase with the distance from the liquid-steel meniscus, consequently causing an increase in the heat resistance (Figure 1).

The heat-transport mechanism between the solidifying strand shell and the mould wall may be divided into two components - conduction and radiation. The convection in this area may be neglected due to the small size of the air gap. The total air-transfer coefficient on the strand mould path may be presented with the following Equation:

$$
q_{\mathrm{wk}}=q_{\mathrm{c}}+q_{\mathrm{r}}
$$

where:

$q_{\mathrm{wk}}$ - total heat-flux density,

$q_{\mathrm{c}}-$ conducted heat-flux density,

$q_{\mathrm{r}}$ - density of the heat flux transferred by radiation.

$T_{\mathrm{M}}$ - temperature of the mould, $T_{\mathrm{S}}$ - temperature of the strand surface, $T_{\mathrm{SS}}$ - temperature of the solid layer of the slag, $T_{\mathrm{MS}}$ - the melting point of the slag, $T_{\mathrm{LS}}-$ temperature of the liquid layer of the slag, $T_{\mathrm{SO}}-$ solidus temperature. ${ }^{5}$

Finally, the flux density of the heat flowing from the strand to the mould is calculated from the Newton law:

equivalent layer of the oscillating surface defects

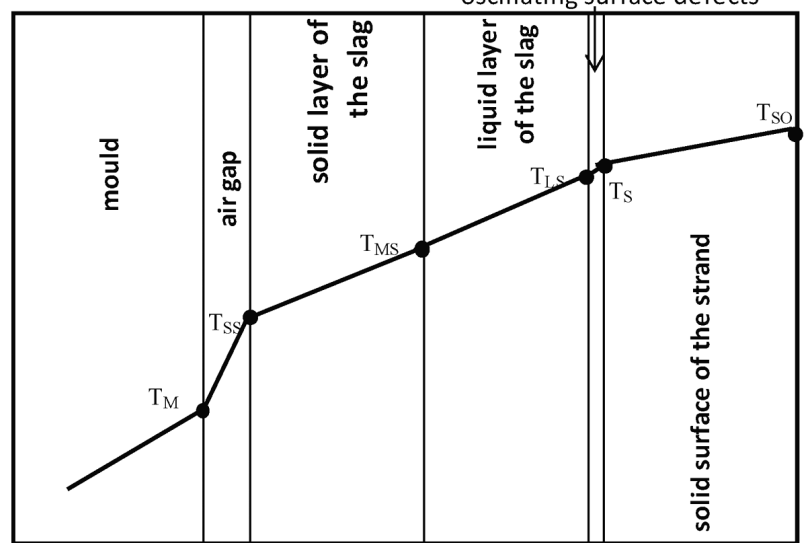

Figure 1: Structure of the layer between the mould and the shell Slika 1: Zgradba področja med kokilo in strjeno skorjo

$$
q_{\mathrm{c}}=\frac{T_{\mathrm{wl}}-T_{\mathrm{kr}}}{r_{\mathrm{sz}}}=\alpha_{\mathrm{sz}}\left(T_{\mathrm{wl}}-T_{\mathrm{kr}}\right)
$$

where:

$\alpha_{\mathrm{sz}}-$ coefficient of the heat transfer through the air gap, $r_{\mathrm{sz}}-$ air gap thermal resistance.

The outer side of the mould is intensely cooled with water, flowing through the channels. Here, the heat is transferred by forced convection. The calculation of the heat-transfer coefficient, with the water cooling in the mould channels, on the basis of the available formulas, is complex because of the method of heat transfer to the water flowing through the channel. Assuming the distribution of the channel density at the perimeter of the mould varies, it is possible to obtain a few cooling programs. To determine the average heat-transfer coefficient, the following formula may be applied to the outer surface of the mould: ${ }^{6}$

$$
\alpha_{\mathrm{w}}=\frac{N u \lambda_{\mathrm{w}}}{d_{\mathrm{k}}} x_{\mathrm{k}}
$$

where:

$x_{\mathrm{k}}$ - water-cooled mould-surface share,

$d_{\mathrm{k}}-$ mould-channel diameter,

$\lambda_{\mathrm{w}}-$ heat-transfer coefficient for water,

$\mathrm{Nu}$ - Nusselt number.

For the forced convection (the water flowing in the mould channels) the Nusselt number is represented by the relationship between the Reynolds $(R e)$ number and the Prandtl $(P r)$ number:

$$
N u=\mathrm{f}(\operatorname{Re}, P r)
$$

The Mikheyev formula may be selected to determine the Nusselt number:?

$$
N u=0.021 \operatorname{Re}^{0.8} \operatorname{Pr}_{\mathrm{w}}^{0.43}\left(\frac{P r_{\mathrm{w}}}{P r_{\mathrm{s}}}\right)^{0.25}
$$

The Reynolds $R e$ and Prandlt $P r$ numbers in Equation (7) are determined at the water properties for the mouldwall temperature (the $\mathrm{s}$ index) and the mean water temperature in the channel (the $\mathrm{w}$ index).

After leaving the mould, the slab surface is cooled with a water spray and in the air. The heat flux that is carried away from the surface of the solidifying strand is proportional to the temperature difference between the strand surface and the cooling medium temperature. In this zone it is recommended to maintain the cooling intensity which leads to gradual temperature changes. It ensures that the cracks generated by thermal stresses are avoided. ${ }^{8}$

In the secondary cooling zone, the heat exchange with the environment is accompanied by several mechanisms:

- direct impact of the water stream on the strand,

- cooling with the water flowing on the surface and with defected drops, 
- cooling with the water lingering on the roll in the formed hollow,

- cooling the places located directly under the roll with the ambient air,

- cooling through the contact faces of the roll.

The heat transfer from the surface of the solidifying strand is a complex process due to the nature of the heat exchange accompanying the boiling effect. When the surface of the strand leaving the mould is cooled, film boiling prevails. At this stage, the main mechanism of the heat transfer is the conduction through the vapour film resulting from supplying water to the hot surface of the strand via the nozzles. The heat-transfer mechanism is also accompanied by radiation, therefore, the lower the strand surface temperature, the lower is the value of the heat-transfer coefficient. ${ }^{9}$ Drops of cooling water that fall onto the hot strand surface evaporate, forming a film that restricts water access at this spot. The water momentum is the highest in the centre of the cooling area, enabling the vapour film to be broken and allowing a direct contact between the water and the cooled strand surface. It intensifies the cooling process in this area, therefore, the amount of the heat received strongly depends on the liquid velocity. ${ }^{5}$

During further cooling, as the temperature falls below the Leidenfrost point, the transition-boiling effect occurs. In the vapour film, vapour bubbles form, consequently leading to a break and decay of the vapour film. It causes an increase in the heat-transfer coefficient. ${ }^{10}$ During further cooling we observe the effect of bubble boiling, along with a further decline in the heat-transfer coefficient. After the completion of the bubble-boiling stage and the cessation of the conditions for vapour forming, the strand surface is cooled by forced convection. ${ }^{11}$ Figure 2 presents the change in the heat-transfer coefficient for the water-boiling process.

A very important mechanism of the heat exchange in the secondary cooling zone is radiation due to the surface temperature of the strand that leaves the mould. To obtain a complete description of the effects, it is necessary to consider the heat-flux density resulting from the heat transfer by radiation. The radiation term may be expressed with the Stefan-Boltzman law:

$$
q_{\mathrm{rad}}=\varepsilon_{\mathrm{wl}} \sigma\left(T_{\mathrm{wl}}^{4}-T_{\mathrm{a}}^{4}\right)
$$

where:

$q_{\text {rad }}$ - heat-flux density lost by the strand surface to the environment,

$\sigma-$ Stefan-Boltzman radiation constant,

$\varepsilon_{\mathrm{wl}}$ - total emissivity of the strand surface,

$T_{\mathrm{a}}-$ ambient temperature.

The strand emissivity-coefficient value may be adopted in the range of $0-1$. Due to a simplification, the constant may be assumed to be 0.85 .

The flux density of the heat transferred to the cooling water may be calculated from the following relationship:

$$
q_{\text {spray }}=\alpha_{\text {spray }}\left(T_{\text {wl }}-T_{\text {spray }}\right)
$$

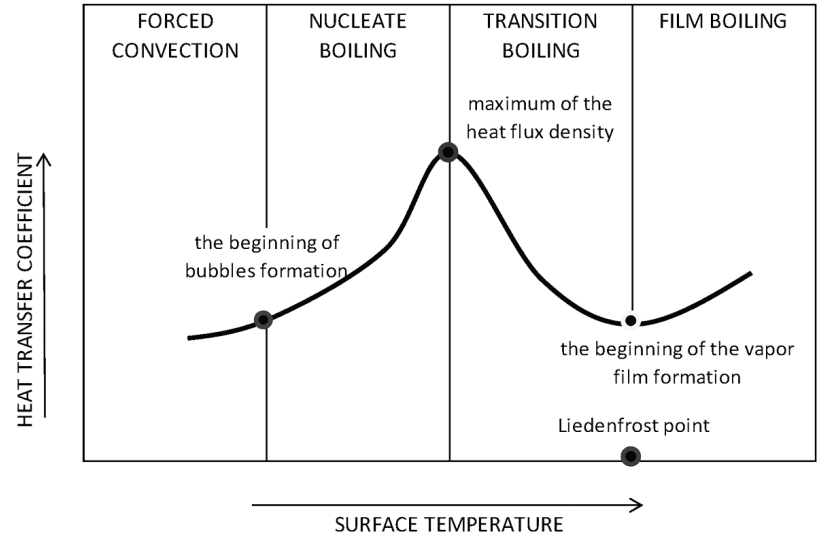

Figure 2: Flow diagram for the heat-transfer coefficient changing during the boiling process ${ }^{3}$

Slika 2: Potek spreminjanja koeficienta prenosa toplote med vrenjem ${ }^{3}$

where:

$\alpha_{\text {spray }}-$ coefficient of heat transfer by water,

$T_{\mathrm{wl}}$ - strand surface temperature,

$T_{\text {spray }}$ - temperature of the water flowing through the nozzles.

In order to calculate the flux density of the heat transferred, it is necessary to know the heat-transfer coefficient $\alpha_{\text {spray. }}$. The relationship describing the heat-transfer coefficient of the heat transferred as a result of the water-spray impact may be expressed in a general form: ${ }^{4}$

$$
\alpha_{\text {spray }}=A \dot{V}_{\text {spray }}^{\mathrm{c}}\left(1-b t_{\text {spray }}\right)
$$

where:

$\alpha_{\text {spray }}-$ heat-transfer coefficient,

$A, b, c$-empirical constants,

$\dot{V}_{\text {spray }}^{\mathrm{c}}$ - cooling-water flux,

$t_{\text {spray }}$ - temperature of the water flowing through the nozzles.

The heat-transfer coefficient depends on the conditions that occur during the contact of the water with the surface of the solidifying strand. The water-flux density, the velocity of the water flowing out of the spray nozzle,

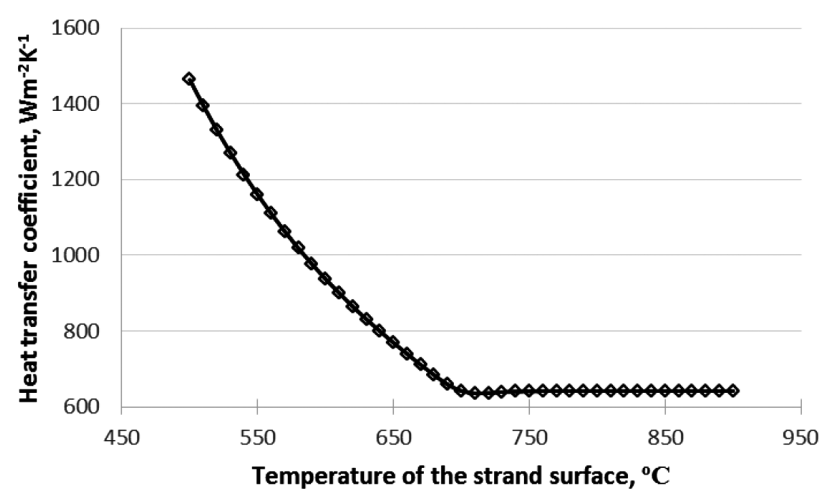

Figure 3: Heat-transfer coefficient during the cooling process with a water spray for $\dot{V}_{\text {spray }}^{\mathrm{c}}=3 \mathrm{dm}^{3} \mathrm{~m}^{2} \mathrm{~s}^{-1}$

Slika 3: Koeficient prenosa toplote med ohlajanjem z brizganjem vode pri $\dot{V}_{\text {spray }}^{\mathrm{c}}=3 \mathrm{dm}^{3} \mathrm{~m}^{2} \mathrm{~s}^{-1}$ 
the nozzle type and the water pressure all influence the value of the coefficient. A typical course of the changes in the heat-transfer coefficient as a function of the temperature is presented in Figure 3.

If the solidifying cast-strand surface temperature is not known, a simplified formula may be applied: ${ }^{1}$

$$
\alpha_{\text {spray }}=10 v+(107+0.688 v) \dot{V}_{\text {spray }}
$$

where: $v$ - water-drop speed.

Equation (11) may be applied for water fluxes from $0.3 \mathrm{dm}^{3} \mathrm{~m}^{-2} \mathrm{~s}^{-1}$ to $9.0 \mathrm{dm}^{3} \mathrm{~m}^{-2} \mathrm{~s}^{-1}$ and speeds from $11 \mathrm{~m} \mathrm{~s}^{-1}$ to $32 \mathrm{~m} \mathrm{~s}^{-1}$. The values obtained for a flux of $=3 \mathrm{dm}^{3} \mathrm{~m}^{-2} \mathrm{~s}^{-1}$ and the average water speeds are about $600 \mathrm{~W} \mathrm{~m}^{-2} \mathrm{~K}^{-1}$.

In the zone beyond the water sprays, in most of the continuous-casting machines, after a strand leaves the secondary-cooling chamber, a heat transfer occurs between the hot surface of the strand cooled and the ambient atmospheric air. Radiation is the prevailing mechanism of heat transfer; however, the heat is partly transported from the strand surface with free or forced convection. ${ }^{3}$

Even an abbreviated description of the heat-transfer mechanisms in the steel continuous-casting process indicates two basic difficulties accompanying the mathematical modelling of the process. First, it is impossible to identify every component of the model. If the description is very detailed, taking into account all the partial processes, then, at the verification stage, simplifications are usually made and substitute heat-transfer coefficients are determined. However, these simplifications do not cover all the problems that are encountered. The second stage of verification always requires us to find the relationship between the identified values of the heat-transfer coefficients and the intensity of the cooling-media supply. The fulfilment of this requirement is the key to the correctness of the forecast of each continuous-casting model and it is a problem most difficult to solve.

\section{TYPES OF MATHEMATICAL MODELS}

\subsection{Lagrangian mesh model}

The motion of a continuum may be described from two different standpoints - either with the Lagrangian or Eulerian method. The motion analysis, together with these methods, allows one to determine the position of any moving element of a body; in addition, these elements are treated as material points. The Lagrangian description is preferred in solid-body mechanics. In this model the "observer" follows the body's material points, observing their temperature and velocity being affected by specific boundary conditions. The initial positions of the material points influence the course of the process. As a result, the history of a numerically modelled process can be created on the basis of the temperature field and velocity (strain) field, allowing a calculation of the stress field in the body and the changes in the microstructure and porosity. Another advantage of the Lagran-

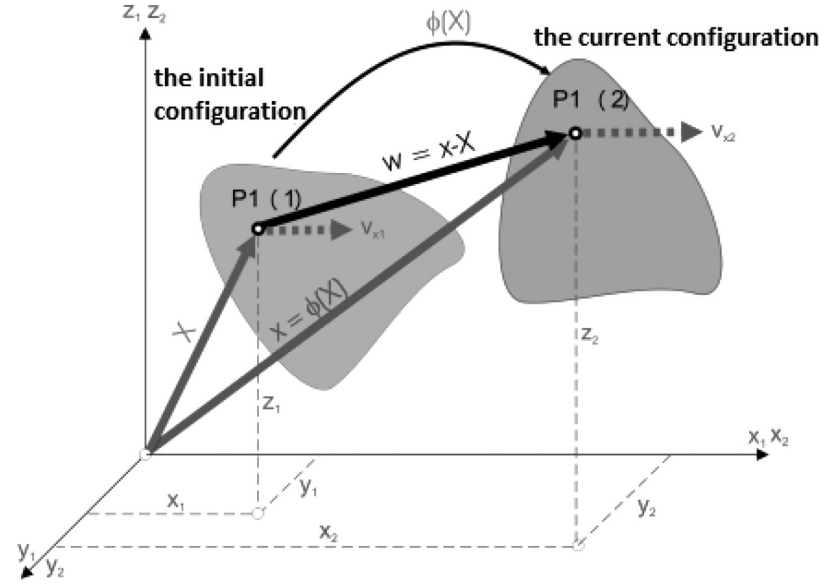

Figure 4: Lagrangian Method - description of the motion of the object $^{5}$

Slika 4: Lagrange-jeva metoda - opis gibanja predmeta ${ }^{5}$

gian description is the fact that the mesh deforms together with the body, which is particularly relevant in the numerical modelling of body strains. In the Lagrangian method an object's motion (physical continuum) is described by the dependence of the coordinates of all the particles on the time and the initial position for $\tau=0$ or the initial time $\tau_{1}$. A necessary condition is also the determination of all the properties of the object, taking into account the positions of its points at a specific time. By eliminating the time, we can obtain an equation of the trajectory of the object particles. In this method, the observer moving together with the object maintains contact with the same object particles at the set time. ${ }^{5}$ This is schematically presented in Figure 4.

\subsection{Eulerian mesh model}

The Eulerian method is usually used in fluid mechanics. Contrary to the Lagrangian description, the reference point is located outside the area, so the "observer" follows the behaviour of the area from the outside. In the Eulerian method, bodies move on the background of a mesh that represents a specific area. If, during the motion of the fluid in the system, the temperature, the velocity vector and the concentrations do not change with the time at the fixed points, the external "observer" interprets the system as a steady system. Only by analysing the

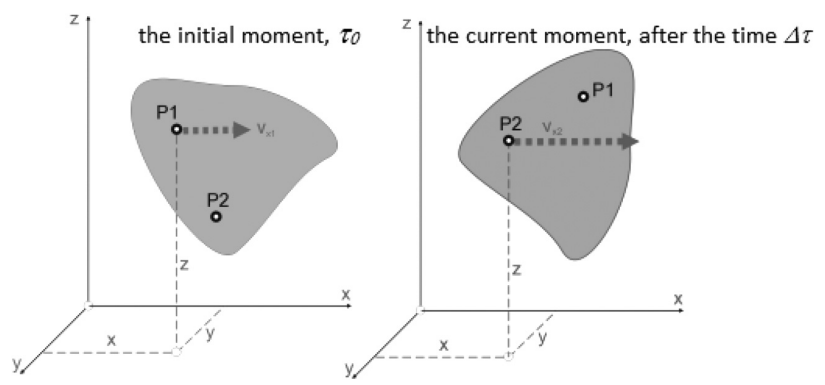

Figure 5: Euler Method - description of the motion of the object ${ }^{5}$ Slika 5: Euler-jeva metoda - opis gibanja predmeta ${ }^{5}$ 
data concerning the temperature field and the velocity, does it turn out that, in fact, the process of the system is transient.

The time and coordinates of the current configuration are independent variables. Such a description is called the Eulerian description or spatial description because the changes in the medium parameters at a specific place in the space are tracked. In Figure 5 this place is determined by the coordinates $x, y, z$. At the initial moment, these coordinates describe the position of element $P l$ in the object, whereas after time $\Delta \tau$, at the moment of the current observation, they describe the position of a different element, $P 2$. So, at various times various elements are located at the same place. This method of description is very favourable for the objects whose initial configuration has no influence, or their influence on the state of the configuration at a later time is of little significance. It is particularly significant for the description of the movement of fluids, i.e., liquids and gases. ${ }^{9}$

\subsection{MiLE method}

In the process of steel continuous casting, the solid and liquid phases occur simultaneously and, in the metallurgical part of the strand, these phases are adjacent. So, the problem of numerical modelling of this part of the process must be solved with both methods the Lagrangian and Eulerian methods - or their combination. In the numerical model using the finite-element method, the Eulerian approximation is used to describe the temperature field and the liquid-metal flow. A fixed mesh with invariable geometry may be used here. The speed and temperature vectors are determined in fixed node points. To model the strain and stress of the solidified metal simultaneously, it is necessary to use the description with the Lagrangian coordinates.

At present, a new method combining the Lagrangian and Eulerian methods is used for a numerical simulation of the steel continuous-casting process - the MiLE (mixed Lagrangian-Eulerian method) method. In this method the continuous-casting-process area is divided into two parts. The upper, stationary, part is described by the Eulerian scheme. The lower part is described by the Lagrangian scheme as it moves at the casting speed. To maintain the strand integrity, at consecutive time steps,

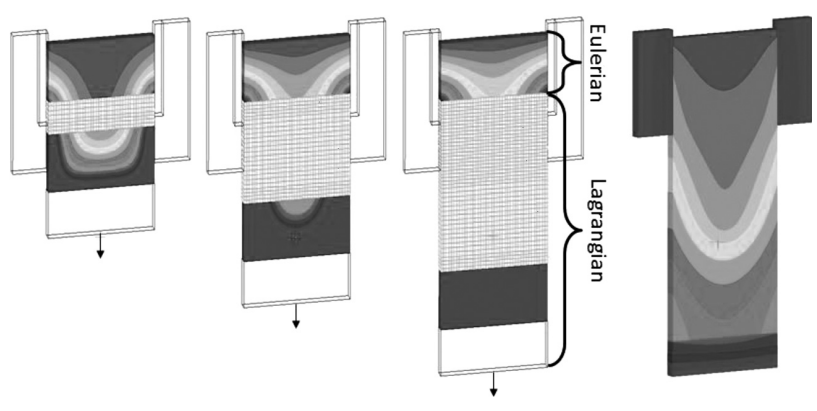

Figure 6: MiLE algorithm ${ }^{5}$ Slika 6: MiLE-algoritem ${ }^{5}$ layers are placed under the upper part; these layers bring, into the lower part, a mass of steel equivalent to the mass of the steel brought to the mould from the tundish.

The MiLE method allows linked modelling of the non-stationary temperature fields and of the liquid-steel flow in the process of steel continuous casting and modelling of the stresses caused by thermal effects.

The principle of the MiLE algorithm is presented in Figure 6. The first action is the division of the strand into two areas. After starting the casting process, the lower area moves downwards, whereas the upper area stays in its initial position. The calculations within this area are performed with the Eulerian model. To maintain the integrity between the areas, the mesh must be successively supplemented with additional layers of elements, forming a dynamic area. Therefore, a certain number of elements with the initial thickness of zero are stored within the area between the first two areas (the third area). In order to ensure the integrity of the temperature field and the velocity field between areas 1 and 3 , in all the nodes of the "stored" (not yet used) layers, momentary boundary conditions are imposed. The same values of the temperature and velocity are assigned to the nodes with identical coordinates., ${ }^{5,12}$ In areas 2 and 3, the Lagrangian model is used for the calculations (Figure 6).

\section{SENSITIVITY OF STEEL-CONTINUOUS- CASTING-PROCESS MODELS}

\subsection{Numerical parameters}

The procedure of a mesh application arises from calculation tests and not from formal guidelines. For each new case, applying a FEM mesh is an individual issue for a specific model. For a new mesh (use of different elements or their sizes), a number of calculation tests should be performed in order to eliminate potential numerical errors. At the stage of the FEM mesh design, the places of the implementation of the boundary conditions should be taken into account due to the refinement of the mesh at those places, regardless of the applied mesh type. An observation of the obtained results, in particular the temperature distribution, allows an easy identification of the places where a numerical error related to the mesh-element size is generated. Usually a temperature-distribution asymmetry is noticeable. In addition, a high jump in the temperature values can be noticed. This is neither correlated with the boundary conditions nor justified by the change in the main process parameters in this area.

\subsection{Material parameters}

The thermophysical properties of steel - as determined by experimental research or calculated using thermodynamic databases - are the key input parameters for building a numerical model of the continuous-casting process. Based on the chemical composition of a steel 
grade, and the algorithms implemented in the thermodynamic databases, a number of material properties, i.e., enthalpy, thermal conductivity, density, viscosity, solidus and liquidus temperatures, may be determined. The calculation of the material parameters of the steel grade tested based on its chemical composition is a common approach. However, it should be emphasised that the temperature distribution obtained with the numerical modelling is extremely sensitive to any changes in the basic thermophysical properties.

The starting point for the sensitivity analysis was the base variant, which took account of the specific heat values from the experimental tests, along with the latent heat value that was implemented in the numerical model as a numerical value. The calculations obtained for the base variant allowed the actual continuous-casting process for the S235 steel grade to be fully mapped for the declared strand casting speed of $1 \mathrm{~m} / \mathrm{min}$. The other variants were defined by the $c_{\mathrm{p}}$ declaration, as follows:

Variant 1, where the magnetic-transformation heat and the austenite-ferrite-transformation heat were considered. The heat of the fusion was declared as 113 $\mathrm{kJ} / \mathrm{kg}$.

Variant 2, where the magnetic-transformation heat, the austenite-ferrite-transformation heat and, additionally, the peritectic-transformation heat were considered. The heat of the fusion was declared as 113 $\mathrm{kJ} / \mathrm{kg}$.

Variant 3, where the magnetic-transformation heat, the austenite-ferrite-transformation heat, the peritectictransformation heat and the heat of fusion were considered.

The obtained calculation results are presented in Table 1.

Table 1: Metallurgical length and shell thickness calculated for the selected variants

Tabela 1: Metalurška dolžina in debelina skorje, izračunana za izbrane variante

\begin{tabular}{|c|c|c|}
\hline $\begin{array}{c}\text { Specific heat, } \\
\mathrm{kJ} /(\mathrm{kg} \mathrm{K})\end{array}$ & $\begin{array}{c}\text { Metallurgical } \\
\text { length, } \mathrm{m}\end{array}$ & $\begin{array}{c}\text { Thickness of the } \\
\text { shell, } \mathrm{cm}\end{array}$ \\
\hline Basic & 12.6 & 2.2 \\
\hline Variant 1 & 12.6 & 2.2 \\
\hline Variant 2 & 13.7 & 2.18 \\
\hline Variant 3 & 11.4 & 2.21 \\
\hline
\end{tabular}

The method of determining the specific heat value, along with the solidifying heat, has a significant influence on the obtained results of the numerical model. By taking into account the values coming from the experimental research, the amount of the heat accompanying the individual phase transformations occurring during the solidification process may be accurately determined. In addition, the method determining the latent heat is very important. In extreme cases, an error in the enthalpy-value determination in relation to the verified specific-heat values may be as high as $178{ }^{\circ} \mathrm{C}$.

\subsection{Process parameters (boundary conditions)}

The influence of the boundary conditions assumed for the calculations, apart from the thermophysical parameters, is the most important element of any mathematical model of the continuous-casting process. However, in professional references there is an extremely huge range of the values assumed. To illustrate the scale of the problem, the values of the heat-transfer coefficients (HTC) for 12 various models describing the heat transfer in a mould were collected in Table 2. ${ }^{3,13-25}$ Next, calculations with the specified HTC values were performed, maintaining the constant value of the other process parameters. The obtained calculation results are presented in Table 3.

Table 2: Heat-transfer coefficient in the primary cooling zone Tabela 2: Koeficient prenosa toplote $\mathrm{v}$ primarni hladilni coni

\begin{tabular}{|c|c|c|}
\hline No. & Average or maximum value & Reference \\
\hline \multicolumn{3}{|c|}{$\begin{array}{l}\text { Group I - the average HTC value along the whole length of } \\
\text { the mould }\end{array}$} \\
\hline 1 & $h=1200 \mathrm{~W} /\left(\mathrm{m}^{2} \mathrm{~K}\right)$ & 13,14 \\
\hline 2 & $h=1300 \mathrm{~W} /\left(\mathrm{m}^{2} \mathrm{~K}\right)$ & 15 \\
\hline 3 & $h=1500 \mathrm{~W} /\left(\mathrm{m}^{2} \mathrm{~K}\right)$ & 16,17 \\
\hline \multicolumn{3}{|c|}{ Group II - two values of heat-transfer coefficients } \\
\hline 4 & $\begin{array}{c}h_{1}=1163 \mathrm{~W} /\left(\mathrm{m}^{2} \mathrm{~K}\right) \text { for } z=0.6 \mathrm{~m} \\
h_{2}=1395.6 \mathrm{~W} /\left(\mathrm{m}^{2} \mathrm{~K}\right) \text { for } z>0.6 \mathrm{~m}\end{array}$ & 18,19 \\
\hline \multicolumn{3}{|c|}{ Group III - linear variable } \\
\hline 5 & $h=2000-800 \mathrm{~W} /\left(\mathrm{m}^{2} \mathrm{~K}\right)$ & 20 \\
\hline 6 & $h=1500-600 \mathrm{~W} /\left(\mathrm{m}^{2} \mathrm{~K}\right)$ & 20 \\
\hline \multicolumn{3}{|c|}{ Group IV - variable (various heat-transfer mechanisms) } \\
\hline 7 & $h_{\max }=1300 \mathrm{~W} /\left(\mathrm{m}^{2} \mathrm{~K}\right)$ & 21 \\
\hline 8 & $h_{\max }=2500 \mathrm{~W} /\left(\mathrm{m}^{2} \mathrm{~K}\right)$ & 22 \\
\hline 9 & $h_{\max }=2000 \mathrm{~W} /\left(\mathrm{m}^{2} \mathrm{~K}\right)$ & 23 \\
\hline 10 & $h_{\max }=1300 \mathrm{~W} /\left(\mathrm{m}^{2} \mathrm{~K}\right)$ & 3 \\
\hline 11 & $h_{\max }=3097 \mathrm{~W} /\left(\mathrm{m}^{2} \mathrm{~K}\right)$ & 24 \\
\hline 12 & $h_{\max }=1600 \mathrm{~W} /\left(\mathrm{m}^{2} \mathrm{~K}\right)$ & 25 \\
\hline
\end{tabular}

Table 3: Comparison of the shell thicknesses and temperatures for the selected models of the heat-transfer coefficient

Tabela 3: Primerjava debeline skorje in temperature pri izbranih modelih koeficienta prenosa toplote

\begin{tabular}{|c|c|c|}
\hline Model & $\begin{array}{c}\text { Thickness of the shell after } \\
\text { leaving the mould, cm }\end{array}$ & Temperature, ${ }^{\circ} \mathrm{C}$ \\
\hline 1 & 2 & 836 \\
\hline 2 & 2.3 & 812 \\
\hline 3 & 2.75 & 772 \\
\hline 4 & 2.27 & 833 \\
\hline 5 & 2.38 & 900 \\
\hline 6 & 1.94 & 956 \\
\hline 7 & 1.98 & 976 \\
\hline 8 & 1.92 & 1050 \\
\hline 9 & 1.86 & 1090 \\
\hline 10 & 1.82 & 1099 \\
\hline 11 & 2.51 & 874 \\
\hline 12 & 2.52 & 938 \\
\hline
\end{tabular}

It should be stressed that model 12 is the author's own model, verified under industrial conditions. Its accuracy was checked with test-strand temperature measure- 
ments. The results of this verification are presented in Table 4.

Table 4: Values of the strand surface temperature calculated and measured at the reference points

Tabela 4: Vrednosti izmerjene in izračunane temperature na površini žile v referenčnih točkah

\begin{tabular}{|c|c|c|}
\hline & $\begin{array}{c}\text { The average } \\
\text { measured } \\
\text { temperature, }{ }^{\circ} \mathrm{C}\end{array}$ & $\begin{array}{c}\text { The calculated } \\
\text { temperature, }{ }^{\circ} \mathrm{C}\end{array}$ \\
\hline Measurement point I & 855 & 861 \\
\hline Measurement point II & 905 & 912 \\
\hline
\end{tabular}

\section{STRATEGY OF SELECTING THE STRAND COOLING PARAMETER}

From the perspective of the applicable technology and the design of the slab-continuous-casting machine, it is essential to maintain the metallurgical length at a constant level. This is mostly related to the location of the soft reduction zone. The use of soft reduction of a strand allows an elimination of the axial porosity, consequently, improving the quality of the steel semi-products obtained. Maintaining a comparable metallurgical length for various strand casting speeds guarantees the safety during the continuous-casting process as the strand is fully solidified before shearing. For most of the continuous-casting machines, the best area where the total solidification of the strand should occur is the area before the exit from the secondary-cooling chamber. It is related to the location of the soft-reduction zone and the location of the last point of strand straightening.

The first step of the proposed method for determining the new cooling values is to calculate the influence of a change in the strand withdrawal speed on the metallurgical length, while verifying the shell thickness and the temperature at the reference points. An analysis of the sensitivity of the numerical model of the steel continuous-casting process to the casting speed allows a determination of the percentage impact of the change in the casting speed on the metallurgical length. Knowing this dependence allows us to calculate the influence of a change in the cooling parameters, which must always be correlated with the casting speed.

The simplest method of determining the new cooling values for the spray zones is using the percentage change in individual heat-transfer coefficients, taking into account the percentage change in the metallurgical length as a function of the casting speed. From the numerical perspective, the described method is an effective approach. However, determining the new sets of cooling values must be correlated with the existing technology and the relationships of the changes in the water-flow rates for individual spray zones. When the new values of heat-transfer coefficients were determined, minimum changes were applied to the heat-transfer coefficients within the first two cooling zones; more significant changes were introduced to the other spray zones, while

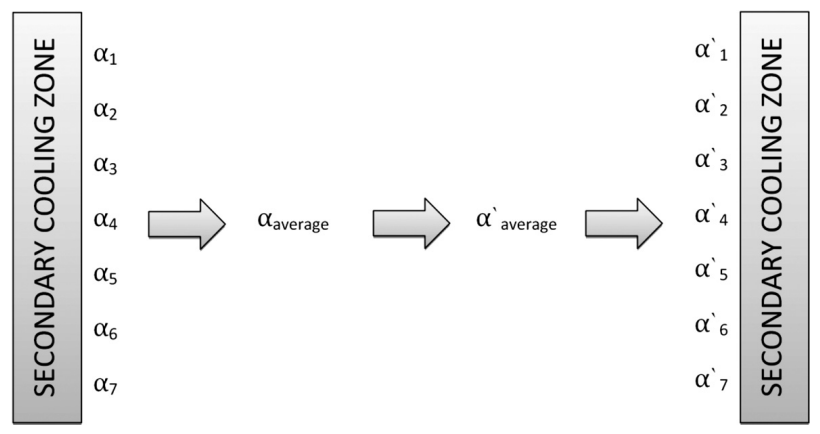

Figure 7: Diagram for a calculation of new heat-transfer coefficients ${ }^{25}$ Slika 7: Prikaz izračuna novih koeficientov prenosa toplote ${ }^{25}$

the temperature increase within the spray zones was controlled. Such an approach is extremely important for maintaining the safety of the steel continuous-casting process.

In the example discussed, for a speed of $1 \mathrm{~m} / \mathrm{min}$, the set of cooling factors remained unchanged, because the desired values of the metallurgical length, the temperature at the reference points and the shell thickness after leaving the mould were obtained. The simulation for the speed of $1 \mathrm{~m} / \mathrm{min}$ was considered the reference for further considerations. Figure 7 presents a diagram of the algorithm for determining the new values of heat-transfer coefficients.

The starting point of the algorithm includes the heattransfer coefficients for seven spray zones; these were calculated on the basis of the actual flows of the water for the three speeds examined. Next, one heat-transfer coefficient for the whole secondary cooling zone $\alpha_{\text {average }}$ was calculated, using the proposed dependence presented with the formula below:

$$
\alpha_{\text {average }}=\frac{\sum_{1}^{n} a_{n} s_{n}}{\sum_{1}^{n} s_{n}}
$$

where:

$\alpha_{\mathrm{n}}$ - heat-transfer coefficient for the selected spray zone,

$s_{\mathrm{n}}-$ surface area of the specific zone,

$n$ - zone number.

The average heat-transfer coefficients for the secondary cooling zone were calculated from dependence 12 . They were $(305,395$ and 410$) \mathrm{W} \mathrm{m}^{-2} \mathrm{~K}^{-1}$, for the speeds of $(0.6,0.8$ and 1$) \mathrm{m} \mathrm{min}^{-1}$, respectively. Knowing the percentage impact of the casting speed on the metallurgical length, the new heat-transfer coefficients for the secondary cooling zone for the speeds of $0.6 \mathrm{~m} \mathrm{~min}^{-1}$ and $0.8 \mathrm{~m} \mathrm{~min}^{-1}$ were calculated; similar metallurgical lengths were obtained as for the speed of $1 \mathrm{~m} \mathrm{~min}^{-1}$. The following dependence was used:

$$
\alpha_{\text {average }}^{\prime}=\frac{\alpha_{\text {average }}}{k}
$$


where: $k$ - coefficient based on the percentage relationship for the metallurgical length as a function of the casting speed.

The new heat-transfer coefficients for the secondary cooling zone were calculated from dependence 13. For the speed of $0.8 \mathrm{~m} \mathrm{~min}^{-1}$ the average heat-transfer coefficient was $315 \mathrm{~W} \mathrm{~m}^{-1} \mathrm{~K}^{-1}$ and for the speed of 0.6 $\mathrm{m} \mathrm{min}^{-1}$ the average heat-transfer coefficient was about $205 \mathrm{~W} \mathrm{~m}^{-2} \mathrm{~K}^{-1}$. The numerical calculations conducted for the new average values of the heat-transfer coefficient for the secondary cooling zone $\alpha_{\text {average }}^{\prime}$ confirmed the above method was correct. Similar metallurgical lengths of $15.7 \mathrm{~m}$ and $16.5 \mathrm{~m}$ were obtained for the speeds of 0.6 $\mathrm{m} \mathrm{min}^{-1}$ and $0.8 \mathrm{~m} \mathrm{~min}^{-1}$, respectively.

At the next stage, the heat-transfer coefficient was calculated using dependence 12 for each spray zone. The calculations resulted in a few sets of heat-transfer coefficients. The values of the heat-transfer coefficients that met the boundary conditions within the allowed percentage change in the heat-transfer coefficients for the individual spray zones were selected. The boundary conditions were determined on the basis of the actual change in the flows of the cooling water in the spray zones for a selected speed.

\section{CONCLUSION}

The development of a versatile method for the optimum determination of strand cooling parameters in the steel continuous-casting process is an extremely complex issue, requiring that many mutually contradictory criteria be met. The quality requirements related mainly to the structure of the solidified cast strand impose a clear restriction to increasing the casting speed. However, the continuous-casting-machine efficiency must be synchronised with the other nodes of the production line. The flexibility required in this case is related to the necessary response to unexpected events that may change the production rhythm of a steelmaking shop.

The cooling-program determination method in the steel continuous-casting process is based on the verification of the numerical models describing the strand solidification process. The determination of, possibly, all the properties of the cast steel as the function of the temperature is a very important step at the stage of determining the model parameters for the conditions defined as the standard. It mainly concerns the specific heat and the solidification heat, the dynamic viscosity, the density and the heat-transfer coefficient. Carrying out the measurements of the listed properties is, unfortunately, a very complex task, requiring the use of very specialised equipment.

For the mathematical description of the steel continuous-casting process at any particular level, we need to find the appropriate method of selecting the boundary conditions. The determination of the boundary conditions based on the process information is one of the fac- tors that are crucial for the correctness of model calculations. Practically, this means that the amount of the used cooling water needs to be converted into the suitable heat-transfer coefficient.

The task of determining the cooling programme in the steel continuous-casting process is not a deterministic task. The selection of the variant for practical implementation depends largely on the experience of the user of the specific machine. However, the criteria that allow an assessment of the correctness of the assumed solution are strictly defined. The most important are:

- the shell thickness under the mould,

- the strand metallurgical length,

- the strand surface temperature at the selected measurement points,

- the critical stress at the temperature of the shell under the mould,

- the strand structure - in particular, the thickness of the chilled grain zone.

\section{Acknowledgments}

This research project was supported by the European Regional Development Fund - the Operational Programme "Innovative Economy", as a project New Concept for Selection of the Cooling Parameters in Continuous Casting of Steel, POIG.01.03.01-12-009/09.

\section{REFERENCES}

${ }^{1}$ H. F. Schrewe, Continuous Casting of Steel, Verlag Stahleisen, Dusseldorf 1989, p. 179

${ }^{2}$ T. Telejko, Z. Malinowski, M. Rywotycki, Archives of Metallurgy and Materials, 54 (2009) 3, 837-844

${ }^{3}$ M. Rywotycki, K. Milkowska-Piszczek, L. Trębacz, Archives of Metallurgy and Materials, 57 (2012) 1, 385-393, doi:10.2478/ v10172-012-0038-z

${ }^{4}$ Y. Meng, B. G. Thomas, Metallurgical Transactions B, 34B (2003) 3, 685-705, doi:10.1007/s11663-003-0040-y

${ }^{5}$ J. Falkus, A. Buczek, A. Burbelko, P. Drożdż, M. Dziarmagowski, M. Karbowniczek, T. Kargul, K. Milkowska-Piszczek, M. Rywotycki, K. Solek, W. Ślęzak, T. Telejko, L. Trębacz, E. Wielgosz, Modelowanie procesu ciąglego odlewania stali, Wydawnictwo Naukowe Instytutu Technologii Eksploatacji - Państwowy Instytut Badawczy, Radom 2012, p. 328

${ }^{6}$ M. Rywotycki, Z. Malinowski, T. Telejko, Hutnik Wiadomości Hutnicze, 73 (2006) 4, 142-147

${ }^{7}$ S. Wiśniewski, T. S. Wiśniewski, Wymiana ciepła, WNT, Warszawa 1997, p. 437

${ }^{8}$ Z. Kudliński, Technologie odlewania stali, Wydawnictwo Politechniki Śląskiej, Gliwice 2006, p. 305

${ }^{9}$ A. Buczek, Metallurgy and Foundry Engineering, 20 (1994) 3, 311-318

${ }^{10}$ J. T. Cieśliński, Modelowanie wrzenia pęcherzykowego, Wydawnictwo Politechniki Gdańskiej, Gdańsk 2005, p. 148

${ }^{11}$ J. Sengupta, B. G. Thomas, M. A. Wells, Metallurgical and Materials Transactions A, 36 (2005) 1, 187-204, doi:10.1007/s11661-0050151-y

${ }^{12}$ J. M. Drezet, M. Rappaz, Metallurgical and Materials Transactions A, 27A (1996) 10, 3214-3225, doi:10.1007/BF02663872 


\section{J. FALKUS, K. MIŁKOWSKA-PISZCZEK: DEVELOPING CONTINUOUS-CASTING-PROCESS CONTROL BASED ...}

${ }^{13}$ M. Biedrońska, R. Grzymkowski, Krzepnięcie Metali i Stopów, 19 (1994), 11-19

${ }^{14}$ M. Biedrońska, R. Grzymkowski, Krzepnięcie Metali i Stopów, 18 (1993), 21-28

${ }^{15}$ A. Kapusta, A. Wawrzynek, Krzepnięcie Metali i Stopów, 18 (1993), 87-94

${ }^{16}$ A. Kapusta, A. Wawrzynek, Krzepnięcie Metali i Stopów, 16 (1987), 150-158

${ }^{17}$ S. H. Seyedein, M. Hasan, International Journal of Heat and Mass Transfer, 40 (1997) 18, 4405-4423, doi:10.1016/S0017-9310(97) 00064-1

${ }^{18}$ X. K. Lan, J. M. Khodadadi, International Journal of Heat and Mass Transfer, 44 (2001) 5, 953-965, doi:10.1016/S0017-9310(00) 00145-9

${ }^{19}$ X. K. Lan, J. M. Khodadadi, International Journal of Heat and Mass Transfer, 44 (2001) 18, 3431-3442, doi:10.1016/S0017-9310(01) 00005-9
${ }^{20}$ R. B. Mahaparta, J. K. Brimacombe, I. V. Samarasekera, Metallurgical and Materials Transactions B, 22B (1991) 6, 875-888, doi:10.1007/BF02651163

${ }^{21}$ J. Falkus, K. Milkowska-Piszczek, M. Rywotycki, E. Wielgosz, Journal of Achievements in Materials and Manufacturing Engineering, 55 (2012) 2, 668-672

${ }^{22}$ J. K. Park, B. G. Thomas, I. V. Samarasekera, Ironmaking and Steelmaking, 29 (2002) 5, 359-375, doi:10.1179/030192302225004601

${ }^{23}$ Z. Malinowski, T. Telejko, B. Hadala, Archives of Metallurgy and Materials, 57 (2012) 1, 325-331, doi:10.2478/v10172-012-0030-7

${ }^{24}$ J. S. Ha, J. R. Cho, B. Y. Lee, M. Y. Ha, Journal of Materials Processing Technology, 113 (2001) 1-3, 257-261, doi:10.1016/S09240136(01)00691-4

${ }^{25}$ K. Milkowska-Piszczek, J. Falkus, Archives of Metallurgy and Materials, 60 (2015) 1, 251-256, doi:10.1515/amm-2015-0040 